Inês Brás Marques, MD

Stuart Flanagan, MD

Heather Noble, MD

Gavin Giovannoni, PhD

Monica Marta, PhD

Neurol Neuroimmunol Neuroinflamm

2015;2:e74; doi: 10.1212/ NXI.0000000000000074

\section{VARICELLA-ZOSTER VIRUS ENCEPHALITIS MIMICKING TOXOPLASMOSIS RELAPSE OPEN}

Case report. A 37-year-old woman was admitted with seizures, confusion, and fever following weeks of apathy and self-neglect. HIV-1 infection and cerebral toxoplasmosis were diagnosed 4 months before, with good clinical and radiologic response to sulfadiazine and pyrimethamine after 1 month $^{1}$ (figure, A). After discharge she had poor adherence to antitoxoplasmosis and antiretroviral drugs.

At this admission, examination revealed slow verbal and motor responses, disorientation, and pyrexia $\left(38^{\circ} \mathrm{C}\right)$. Hemoglobin was $5.9 \mathrm{~g} / \mathrm{dL}, \mathrm{CD} 4=4$ cells $/ \mu \mathrm{L}$ (1\%), and HIV viral load was 114.294 copies/mL. Serologies were reactive for Toxoplasma and negative for Cryptococcus, hepatitis B and C, and syphilis. Brain MRI revealed more gadolinium-enhancing lesions (figure, B). Toxoplasmosis treatment and truvada/ darunavir/ritonavir were restarted, with clinical and radiologic improvement of enhancement pattern after 6 weeks (figure, C).

Two weeks later, clinical worsening ensued, with fluctuating consciousness, apathy, aphasia, and food and medication refusal. MRI showed significant increase in T2/fluid-attenuated inversion recovery lesion number and extension and multiple new hemorrhagic and enhancing lesions following arterial territories (figure, D). CSF analysis showed 8 white cells $/ \mathrm{mm}^{3}$, protein $1,330 \mathrm{mg} / \mathrm{dL}$, and positive varicella-zoster virus (VZV) DNA (negative cryptococcal antigen, HIV, cytomegalovirus, Epstein-Barr virus, herpes simplex virus, and adenovirus PCR, antineuronal antibodies). Acyclovir (10 mg/kg, tid) was added.

Deterioration continued, with no eye or verbal response to stimuli, food and medication refusal, and tetraparesis with hyperreflexia and bilateral extensor plantar response. EEG excluded status epilepticus. CSF showed 1,350 erythrocytes $/ \mathrm{mm}^{3}$, protein 2,400 $\mathrm{mg} / \mathrm{dL}$, no lymphocytes, and lower VZV DNA copies.

VZV hemorrhagic encephalitis with vasculopathy was assumed, so foscarnet $(60 \mathrm{mg} / \mathrm{kg} /$ day $)$ and IV methylprednisolone (3 g over 3 days) were added. Rapid improvement ensued, with the patient being alert with spontaneous eye opening and directing gaze to stimuli after 2 days and showing intentional movements later. Throughout, her attention fluctuated and she refused to engage. Despite considerable clinical improvement, MRI performed 2 months later still demonstrated widespread cerebral lesions (figure, E).

Discussion. Encephalitis etiology frequently remains unknown. ${ }^{2,3}$ In immunosuppressed patients, CNS infections are among the most common complications, but clinical, radiologic, and laboratory features are similar in CNS infections, neoplasms, and HIV encephalopathy. Concurrent CNS pathologies must be considered when patients do not respond to treatment or present with rebound worsening, after excluding treatment nonadherence, drug resistances, misdiagnosis, and immune reconstitution inflammatory syndrome (IRIS). Toxoplasmosis-IRIS is rare, and new perivascular/vascular gadolinium-enhancing lesions extending through perforator territories of middle cerebral arteries with punctate hemorrhagic signal with restricted diffusion-weighted signal areas and CSF VZV DNA were more suggestive of VZV vasculopathy in the case reported.

VZV is estimated to cause $5 \%-8 \%$ of adult encephalitis cases. ${ }^{3}$ Clinical suspicion is essential, especially in immunocompromised patients. In HIV-infected patients, VZV encephalitis is less frequent than tuberculosis, progressive multifocal leukoencephalopathy, cryptococcosis, or primary CNS lymphoma. In addition, its presentation is usually subacute and unspecific (headache, fever, altered consciousness, seizures, and/or focal neurologic deficits $)^{4}$ and the rash is absent. ${ }^{5}$ VZV encephalitis is catastrophic despite therapy, with an estimated 33\% mortality in HIV-infected patients and frequent neurologic sequelae in survivors.

VZV causes a productive infection in arteries, ${ }^{5}$ with secondary inflammation inducing vascular remodeling causing stenosis/occlusion. Hemorrhage can result from necrotizing angiitis or media disruption with aneurysm formation. ${ }^{6}$ Therefore, VZV infection must be considered in cryptogenic stroke patients or CNS vasculitis.

Brain MRI usually shows multiple ischemic lesions typically involving the gray-white matter junction. ${ }^{4}$ Angiographic features include focal stenosis, often with 

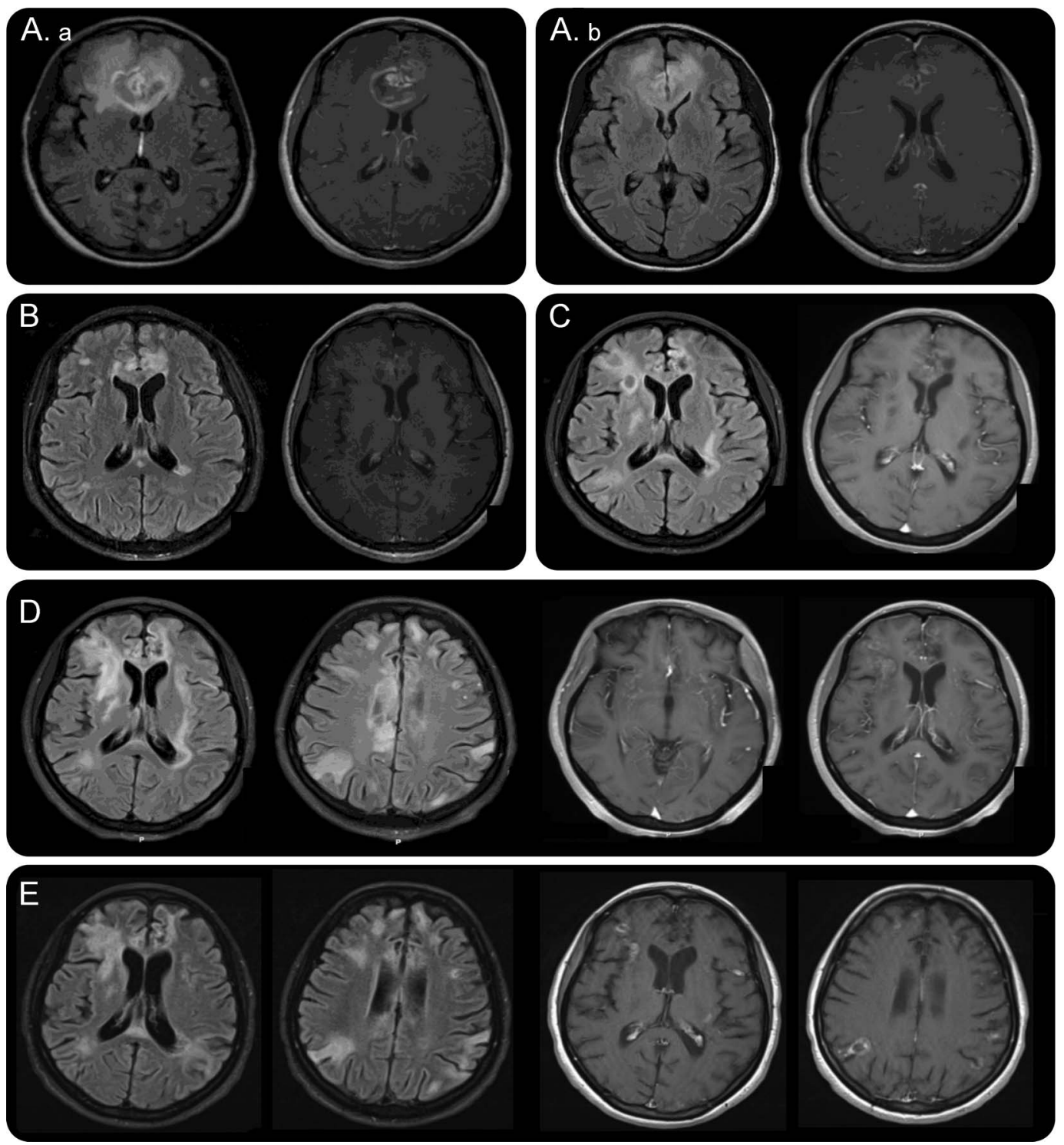

(A) Brain MRI at the time of cerebral toxoplasmosis diagnosis (a) and after 1 month of toxoplasmosis treatment (b). (B) Brain MRI at admission showing increase in lesion number and contrast uptake. (C) Brain MRI showing radiologic response to toxoplasmosis treatment. (D) Brain MRI after progressive clinical deterioration showing increase in lesion number and multiple new enhancing vessels in the perforator and peripheral distribution of middle cerebral artery territories. (E) Brain MRI after 2 months of foscarnet treatment. Despite significant clinical improvement, radiologic lesions persist.

poststenotic dilation. ${ }^{4,5} \mathrm{CSF}$ is normal (40\% of HIVinfected patients) or shows modest pleocytosis, erythrocytes, and/or increased proteins. ${ }^{4}$ VZV DNA in CSF has $98 \%$ specificity and $80 \%$ sensitivity in HIVinfected patients, ${ }^{7}$ with a correlation between the viral load and CNS disease severity. However, VZV DNA becomes undetectable after weeks. ${ }^{5}$ CSF anti-VZV immunoglobulin $\mathrm{G}(\mathrm{IgG})$ has greater diagnostic value, increasing as VZV DNA becomes undetectable.

Optimally, CSF/serum VZV IgG index is needed to confirm intrathecal antibody production. DNA or IgG virologic confirmation in CSF is required for VZV encephalitis diagnosis, and only a negative result in both can rule out this infection. VZV in CSF is not routinely or timely tested, and VZV encephalitis diagnosis may be frequently missed.

First-line treatment for VZV encephalitis is acyclo$\operatorname{vir}\left(10-15 \mathrm{mg} / \mathrm{kg}\right.$, tid, $10-14$ days). ${ }^{2,4}$ In severe cases, oral/IV steroids are an option for arterial inflammation, ${ }^{4}$ but long-term steroids are not recommended. ${ }^{1,4}$ If acyclovir resistance is suspected, foscarnet is advised. ${ }^{1}$

In our patient, timely histopathologic confirmation was impossible; however, VZV DNA in CSF and sustained improvement after foscarnet and steroids support our diagnosis.

Conclusions. VZV encephalitis has an unspecific presentation and may explain a significant proportion 
of cases of encephalitis classified as undetermined. Clinical suspicion is essential and routine screening for VZV in CSF needs to be implemented.

From the Blizard Institute (I.B.M., G.G., M.M.), Queen Mary University London; and Barts Health NHS Trust (S.F., H.N.), London, UK.

Author contributions: Inês B. Marques contributed to data acquisition and drafted the manuscript. Stuart Flanagan contributed to data acquisition and revised the draft critically for important intellectual content. Heather Noble contributed to data acquisition and revised the draft critically for important intellectual content. Gavin Giovannoni revised the draft critically for important intellectual content. Monica Marta contributed to data acquisition, participated in the manuscript design and coordination, and helped to draft the manuscript.

Study funding: No targeted funding reported.

Disclosure: I.B. Marques received research support from Tecnifar. $S$. Flanagan received travel funding from BHIVA/MSD, is on the advisory board for the social media editor at STI Journal, and was an on-air media doctor for BBC. H. Noble reports no disclosures. G. Giovannoni is on the scientific advisory board for Biogen-Idec, Fiveprime, Genzyme, GW Pharma, Ironwood, Merck-Serono, Novartis, Roche, Sanofi-Aventis, Synthon BV, Teva, Vertex Pharmaceuticals, Abbvie, and Canbex; has received honoraria from Biogen-Idec, Genzyme, GW Pharma, MerckSerono, Novartis, Roche, and Teva; is an editor for Multiple Sclerosis and Related Disorders; has consulted for Biogen-Idec, Fiveprime, Genzyme, GQ Pharma, Ironwood, Merck-Serono, Novartis, Roche, Sanofi-Aventis, Synthon BV, Teva, Vertex Pharmaceuticals, Abbvie, and Canbex; is on the speakers' bureau for Novartis and Teva; and has received research support from Genzyme and Merck. M. Marta has received travel funding from Biogen-Idec and Abbott Laboratories and has received research support from Merck-Serono. Go to Neurology.org/nn for full disclosures. The Article Processing Charge was paid by the authors.

This is an open access article distributed under the terms of the Creative Commons Attribution-Noncommercial No Derivative 3.0 License, which permits downloading and sharing the work provided it is properly cited. The work cannot be changed in any way or used commercially.
Received September 15, 2014. Accepted in final form January 8, 2015.

Correspondence to Dr.Marques: i.marques@qmul.ac.uk

1. Masur H, Brooks JT, Benson CA, Holmes KK, Pau AK, Kaplan JE. Prevention and treatment of opportunistic infections in HIV-infected adults and adolescents: Updated Guidelines from the Centers for Disease Control and Prevention, National Institutes of Health, and HIV Medicine Association of the Infectious Diseases Society of America. Clin Infect Dis 2014;58:1308-1311. doi: 10.1093/cid/ciu094.

2. Tunkel AR, Glaser CA, Bloch KC, et al. The management of encephalitis: clinical practice guidelines by the Infectious Diseases Society of America. Clin Infect Dis 2008;47:303-327. doi: $10.1086 / 589747$.

3. Granerod J, Ambrose HE, Davies NW, et al. Causes of encephalitis and differences in their clinical presentations in England: a multicentre, population-based prospective study. Lancet Infect Dis 2010;10:835-844. doi: 10.1016/ S1473-3099(10)70222-X.

4. Gilden D, Cohrs RJ, Mahalingam R, Nagel MA. Varicella zoster virus vasculopathies: diverse clinical manifestations, laboratory features, pathogenesis, and treatment. Lancet Neurol 2009;8:731-740. doi: 10.1016/S1474-4422(09)70134-6.

5. Nagel MA, Cohrs RJ, Mahalingam R, et al. The varicella zoster virus vasculopathies: clinical, CSF, imaging, and virologic features. Neurology 2008;70:853-860. doi: 10.1212/ 01.wnl.0000304747.38502.e8.

6. Nagel MA, Traktinskiy I, Azarkh Y, et al. Varicella zoster virus vasculopathy: analysis of virus-infected arteries. Neurology 2011;77:364-370. doi: 10.1212/WNL. 0b013e3182267bfa

7. Corral I, Quereda C, Antela A, et al. Neurological complications of varicella-zoster virus in human immunodeficiency virusinfected patients: changes in prevalence and diagnostic utility of polymerase chain reaction in cerebrospinal fluid. J Neurovirol 2003;9:129-135. doi: 10.1080/13550280390173300. 


\section{Neurology \\ Neuroimmunology \& Neuroinflammation}

Varicella-zoster virus encephalitis mimicking toxoplasmosis relapse

Inês Brás Marques, Stuart Flanagan, Heather Noble, et al.

Neurol Neuroimmunol Neuroinflamm 2015;2;

DOI 10.1212/NXI.0000000000000074

This information is current as of February 12, 2015

\section{Updated Information \& Services}

References

Subspecialty Collections

Permissions \& Licensing

Reprints including high resolution figures, can be found at:

http://nn.neurology.org/content/2/2/e74.full.html

This article cites 7 articles, 0 of which you can access for free at: http://nn.neurology.org/content/2/2/e74.full.html\#\#ref-list-1

This article, along with others on similar topics, appears in the

following collection(s):

Encephalitis

http://nn.neurology.org//cgi/collection/encephalitis

HIV

http://nn.neurology.org//cgi/collection/hiv

Vasculitis

http://nn.neurology.org//cgi/collection/vasculitis

Viral infections

http://nn.neurology.org//cgi/collection/viral_infections

Information about reproducing this article in parts (figures,tables) or in its entirety can be found online at:

http://nn.neurology.org/misc/about.xhtml\#permissions

Information about ordering reprints can be found online:

http://nn.neurology.org/misc/addir.xhtml\#reprintsus

Neurol Neuroimmunol Neuroinflamm is an official journal of the American Academy of Neurology.

Published since April 2014, it is an open-access, online-only, continuous publication journal. Copyright $@$ 2015 American Academy of Neurology. All rights reserved. Online ISSN: 2332-7812.

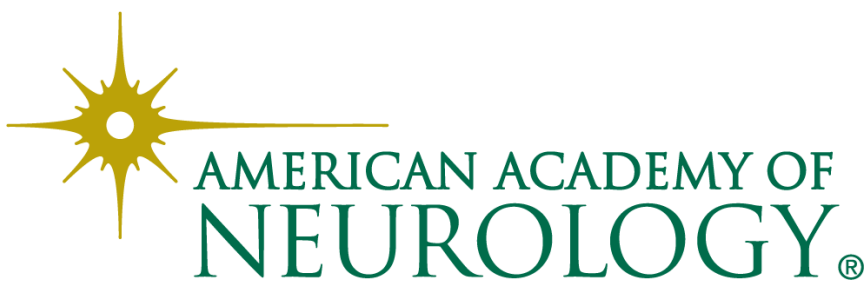

